\title{
STUDI REGENERASI ADSORBEN KULIT JAGUNG (Zea mays L.) DALAM MENYISIHKAN LOGAM BESI (Fe) DAN MANGAN (Mn) DARI AIR TANAH
}

\author{
Shinta Indah dan Rohaniah \\ Laboratorium Air Jurusan Teknik Lingkungan Universitas Andalas \\ Email: ishinta1234@yahoo.com
}

\begin{abstract}
ABSTRAK
Limbah kulit jagung terbukti dapat digunakan sebagai adsorben dalam penyisihan logam Fe dan Mn dalam air tanah. Penelitian ini bertujuan untuk menguji kemungkinan regenerasi kulit jagung dengan menggunakan agen desorpsi $\mathrm{HCl}$ 0,1 M, NaOH 0,1 M, dan akuades, berturut-turut sebagai agen asam, basa, dan netral. Proses adsorpsi-desorpsi dilakukan secara batch selama satu jam dengan dua kali reuse adsorben. Hasil penelitian menunjukkan bahwa secara berturut-turut persentase desorpsi Fe dan Mn dengan menggunakan $\mathrm{HCl}$ 0,1 $\mathrm{M}>\mathrm{NaOH} \mathrm{0,1} \mathrm{M>} \mathrm{akuades.} \mathrm{Kapasitas} \mathrm{adsorpsi} \mathrm{Fe} \mathrm{dan} \mathrm{Mn} \mathrm{terbesar}$ diperoleh dari kulit jagung yang telah didesorpsi dengan akuades yaitu 0,329 $\mathrm{mg}$ Fe/g g dan 0,246 $\mathrm{mg} \mathrm{Fe/g}$ dan 0,094 $\mathrm{mg} \mathrm{Mn/g}$ dan 0,096 $\mathrm{mg} \mathrm{Mn} / \mathrm{g}$, masing-masing pada reuse I dan reuse II. Pada percobaan menggunakan air tanah asli dengan agen desorpsi akuades, diperoleh kapasitas adsorpsi Fe dan Mn dari

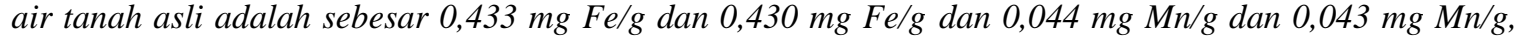
berturut-turut pada reuse I dan reuse II. Penelitian menunjukkan bahwa akuades merupakan agen terbaik untuk regenerasi kulit jagung yang telah digunakan dalam penyisihan logam Fe dan Mn, ditinjau dari kapasitas adsorpsi yang dihasilkannya.
\end{abstract}

Kata kunci: adsorpsi, kulit jagung, Fe, Mn, regenerasi

\section{ABSTRACT}

The feasibility of regeneration of maize husk for iron $(\mathrm{Fe})$ and manganese $(\mathrm{Mn})$ removal was investigated using $0.1 \mathrm{M} \mathrm{HCl}, 0.1 \mathrm{M} \mathrm{NaOH}$ and distilled water as acidic, basic and neutral desorption solutions, respectively. Adsorption and desorption studies were carried out in batch process for $1 \mathrm{~h}$. The data indicated that $\mathrm{HCl}$ 0,1 $\mathrm{M}$ resulted the highest desorption of Fe and $\mathrm{Mn}$ from maize husk, compared to $\mathrm{NaOH} \mathrm{0,1} \mathrm{M} \mathrm{and} \mathrm{distilled} \mathrm{water.} \mathrm{However,} \mathrm{due} \mathrm{to} \mathrm{their} \mathrm{high} \mathrm{adsorption} \mathrm{capacity} \mathrm{results,} \mathrm{distilled} \mathrm{water}$ was the most effective solution for regeneration of maize husk, reaching 0,329 $\mathrm{mg} \mathrm{Fe/g} \mathrm{g}$ and 0,246 $\mathrm{mg}$ $\mathrm{Fe} / \mathrm{g}$ of adsorption capacity for Fe and 0,094 $\mathrm{mg} \mathrm{Mn/g}$ and 0,096 $\mathrm{mg} \mathrm{Mn} / \mathrm{g}$ of adsorption capacity for Mn, at the first and second reuse of maize husk, respectively. This research demonstrated that maize husk as the agricultural waste is a potential biosorbent for the removal of Fe and Mn from groundwater.

Keywords: adsorption, maize husk, Fe, Mn, regeneration 


\section{PENDAHULUAN}

Di antara logam-logam berat esensial dalam air tanah, kandungan besi ( $\mathrm{Fe}$ ) dan mangan (Mn) biasanya memiliki kadar yang relatif tinggi. Kadar $\mathrm{Fe}$ dapat mencapai 10-100 $\mathrm{mg} / \mathrm{l}$ pada air tanah dalam dengan kadar oksigen yang rendah (Effendi, 2003), sedangkan kadar Mn dapat mencapai $2 \mathrm{mg} / \mathrm{l}$ (Kawamura, 1991). Adsorpsi adalah salah satu metode yang banyak digunakan untuk menyisihkan logam dalam air (Montgomery, 1985). Penggunaan material adsorpsi yang dikategorikan low-cost, seperti biomaterial, dewasa ini mendapat perhatian lebih dari para peneliti (Somerville, 2007).

Salah satu keuntungan menggunakan biomaterial sebagai adsorben adalah mudah diregenerasi. Regenerasi dapat dilakukan melalui desorpsi sehingga logam-logam yang telah disisihkan dapat dikumpulkan kembali (recovery) dan adsorbennya dapat digunakan kembali (reuse). Desorpsi dapat dilakukan dengan mengontakkan adsorben yang telah digunakan dengan larutan yang dikenal dengan agen desorpsi. Agen desorpsi yang digunakan dapat berupa asam, basa, dan netral. Beberapa penelitian tentang proses regenerasi telah dilakukan, seperti penelitian Wankasi et al. (2005) yang menggunakan $\mathrm{HCl} \mathrm{0,1} \mathrm{M,} \mathrm{NaOH} \mathrm{0,1} \mathrm{M,} \mathrm{dan}$ akuades sebagai agen desorpsi logam $\mathrm{Pb}^{2+}$ dan $\mathrm{Cu}^{2+}$ dari Nipa palm dimana pada percobaan ini diperoleh $\mathrm{HCl}$ sebagai agen desorpsi terbaik.

Hasil studi menyatakan bahwa materialmaterial yang mengandung selulosa dapat digunakan untuk mengolah limbah logam berat (Igwe et al., 2005). Kulit jagung merupakan limbah pertanian yang mengandung selulosa dan hemiselulosa pada strukturnya (Kurakake et al., 2001). Penelitian tentang kemampuan kulit jagung sebagai adsorben dalam menyisihkan logam $\mathrm{Cr}(\mathrm{VI})$ dari air telah dilakukan dan didapatkan kapasitas penyerapan sebesar 7,384 mg $\mathrm{Cr}(\mathrm{VI}) / \mathrm{g}$ serbuk kulit jagung (Mardona, 2007). Selain itu, Igwe et al. (2005) juga melakukan penelitian tentang adsorpsi logam $\mathrm{Zn}$ (II), Cd(II), dan $\mathrm{Pb}$ (II) dengan tongkol dan kulit jagung dimana diperoleh kapasitas adsorpsi sebesar 495,9 $\mathrm{mg} \mathrm{Zn/g} \mathrm{adsorben,} \mathrm{456,7} \mathrm{mg} \mathrm{Cd} / \mathrm{g}$ adsorben, dan $493,7 \mathrm{mg} \mathrm{Pb}^{2+} / \mathrm{g}$ adsorben.
Melihat kemampuan kulit jagung sebagai adsorben untuk menyisihkan logam cukup tinggi, suatu penelitian lanjutan sangat dibutuhkan. Penelitian ini bertujuan untuk menguji kemungkinan regenerasi kulit jagung dalam menyisihkan logam $\mathrm{Fe}$ dan Mn dari air tanah. Hasil penelitian diharapkan dapat melengkapi informasi tentang kemampuan kulit jagung sebagai adsorben dalam menyisihkan logam dari air, dalam hal ini logam $\mathrm{Fe}$ dan $\mathrm{Mn}$ dari air tanah.

\section{METODOLOGI PENELITIAN}

\section{Peralatan Penelitian}

Peralatan penelitian meliputi neraca analitik, labu ukur, gelas ukur, jartest, beacker glass, corong, statip dan kertas saring. Konsentrasi Fe dan Mn dalam sampel untuk diukur dengan Spektrofotometer Serapan Atom (SSA).

\section{Persiapan Bahan Percobaan}

Bahan untuk percobaan adalah kulit jagung yang diperoleh dari limbah industri rumah tangga yang berlokasi di Belakang Olo, Padang. Persiapan terhadap kulit jagung mengikuti prosedur penelitian penyisihan logam dengan sekam padi oleh Munaf \& Zein (1997), dimana kulit jagung dibersihkan, dicuci dengan air, dipotongpotong, dan dikeringanginkan di udara terbuka. Kemudian jagung digerinda dan diayak dengan dengan menggunakan sieve shaker untuk menghasilkan jagung berdiameter $(0,075-0,250) \mathrm{mm}$. Sebelum digunakan, kulit jagung mengalami perlakuan aktivasi yang berbeda untuk masing-masing logam. Berdasarkan penelitian tentang variasi aktivasi kulit jagung yang dilakukan oleh Indah, dkk (2007), diperoleh kapasitas penyerapan Fe oleh kulit jagung yang optimum adalah tanpa aktivasi yaitu hanya dicuci dengan air lalu dikeringanginkan selama satu hari (24 jam) sementara proses aktivasi untuk penyerapan logam Mn berupa perendaman dengan etanol selama (2-3) jam setelah sebelumnya dicuci dengan air dan dikeringanginkan. Kulit jagung yang telah direndam kemudian disaring dan dikeringanginkan lagi selama satu hari. Pengeringan kulit jagung dilakukan pada temperatur kamar. 


\section{Persiapan Larutan Percobaan}

Larutan percobaan yang dipersiapkan adalah larutan artifisial $\mathrm{Fe}$ dan $\mathrm{Mn}$ serta agen desorpsi berupa $\mathrm{HCl} \mathrm{0,1} \mathrm{M;} \mathrm{NaOH} \mathrm{0,1} \mathrm{M}$; dan akuades. Sebelum diaplikasikan pada sampel air tanah asli, terlebih dahulu percobaan dilakukan pada larutan artifisial.

\section{Percobaan dengan Menggunakan Larutan Artifisial}

Percobaan dengan menggunakan larutan artifisial dilakukan untuk melihat agen desorpsi terbaik dari tiga variasi larutan yaitu $\mathrm{HCl} 0,1 \mathrm{M} ; \mathrm{NaOH}$ 0,1 M dan akuades. Proses desorpsi dilakukan terhadap kulit jagung yang telah digunakan pada proses adsorpsi. Kondisi yang digunakan pada percobaan adsorpsi berupa $\mathrm{pH}$ influen, berat adsorben, dan konsentrasi influen adalah kondisi optimum yang diperoleh dari penelitian tentang penyerapan logam $\mathrm{Fe}$ dan Mn dengan menggunakan kulit jagung (Indah dkk, 2007). Proses adsorpsi dilakukan dengan dua kali reuse adsorben kulit jagung dan volume larutan artifisial yang digunakan pada adsorpsi awal adalah $100 \mathrm{ml}$ dan berat kulit jagung optimum. Pada saat reuse, volume larutan artifisial disesuaikan dengan perbandingan berat adsorben dengan volume larutan artifisial adsorpsi awal.

Larutan artifisial dimasukkan ke dalam beacker glass yang telah berisi kulit jagung lalu diaduk dengan kecepatan 100 rpm selama 60 menit. Percobaan dilakukan sebanyak tiga kali adsorpsi yang terdiri dari adsorpsi I (awal), adsorpsi II (reuse I) setelah desorpsi I, dan adsorpsi III (reuse II) setelah desorpsi II. Kondisi umum variasi parameter pada percobaan dengan menggunakan larutan artifisial dapat dilihat pada Tabel 1.

Untuk proses desorpsi, volume agen desorpsi ditentukan berdasarkan perbandingan berat terhadap volume pada percobaan yang dilakukan oleh Wankasi et al. (2005). Pada percobaan tersebut, sebanyak $0,25 \mathrm{~g}$ adsorben ditempatkan dalam beberapa beacker glass yang berisi 50 $\mathrm{ml}$ agen desorpsi sehingga pada percobaan ini digunakan perbandingan berat adsorben dengan agen desorpsi adalah 1:200. Agen desorpsi dimasukkan ke dalam beacker glass berisi kulit jagung yang telah digunakan pada adsorpsi dan diaduk dengan kecepatan $100 \mathrm{rpm}$ selama 60 menit. Konsentrasi ion $\mathrm{Fe}$ dan $\mathrm{Mn}$ dalam supernatan dari proses adsorpsi dan desorpsi kemudian diukur dengan SSA pada panjang gelombang 248,3 nm untuk Fe (SNI 06-6989.4-2004) dan 279,5 nm untuk Mn (SNI 06-6989.5-2004).

Agen desorpsi terbaik adalah agen yang memberikan \% desorpsi terbesar sedangkan agen regenerasi adsorben terbaik adalah agen yang memberikan kapasitas adsorpsi terbaik pada saat reuse. Penelitian ini lebih menekankan kepada agen desorpsi yang akan memberikan regenerasi terbaik terhadap adsorben kulit jagung. Hal ini dilihat dari kapasitas adsorpsi yang dihasilkan pada saat reuse adsorben kulit jagung.

Tabel 1. Kondisi Optimum Percobaan

\begin{tabular}{ccccccc}
\hline Logam & $\mathrm{pH}$ & $\begin{array}{c}\text { Berat } \\
(\mathrm{g})\end{array}$ & $\begin{array}{c}\text { Konsentrasi } \\
(\mathrm{mg} / \mathrm{l})\end{array}$ & $\begin{array}{c}\text { Perlakuan } \\
\text { Aktivasi }\end{array}$ & $\begin{array}{c}\text { Kecepatan } \\
\text { Pengadukan } \\
(\mathrm{rpm})\end{array}$ & $\begin{array}{c}\text { Waktu } \\
(\mathrm{menit})\end{array}$ \\
\hline $\mathrm{Fe}$ & 4 & 2 & 10 & Tanpa Aktivasi & 100 & 60 \\
$\mathrm{Mn}$ & 5 & 2 & 2 & Aktivasi Etanol & 100 & 60 \\
\hline
\end{tabular}

\section{Percobaan dengan Menggunakan Sampel Air Tanah Asli}

Percobaan ini dilakukan dengan menggunakan sampel air tanah asli dan menerapkan penggunaan agen desorpsi terbaik pada percobaan desorpsi. Pada percobaan ini juga dilakukan reuse sebanyak dua kali. Pada prinsipnya, prosedur percobaan yang dilakukan sama dengan percobaan menggunakan larutan artifisial.

\section{Pengolahan dan Pembahasan Data}

Pengolahan data dan pembahasan meliputi presentase desorpsi dan kapasitas adsorpsi. Kapasitas adsorpsi dihitung dengan menggunakan persamaan 1 (Yalcinkaya, et.al, 2001).

$\mathrm{Q}=\frac{(\text { Cin }- \text { Cout }) V}{M}$

dimana:

$\mathrm{Q} \quad=$ kapasitas logam yang diperoleh $(\mathrm{mg} / \mathrm{g})$

$\mathrm{C}_{\mathrm{in}} \quad=$ konsentrasi ion logam awal $(\mathrm{mg} / \mathrm{l})$

$\mathrm{C}_{\text {out }}=$ konsentrasi ion logam dalam larutan $(\mathrm{mg} / \mathrm{l})$ 


$$
\begin{array}{ll}
\mathrm{M} & =\text { berat kering adsorben yang digunakan }(\mathrm{g}) \\
\mathrm{V} & =\text { volume larutan }(\mathrm{L})
\end{array}
$$

Persen desorpsi dihitung dengan menggunakan persamaan (2) (Yalcinkaya, et.al, 2001).

$$
\% \text { Desorpsi }=\frac{\text { Jumlah ion yang didesorpsi }}{\text { Jumlah ion yang diadsorpsi }} \times 100 \cdots
$$

\section{HASIL DAN PEMBAHASAN}

\section{Percobaan Adsorpsi-Desorpsi pada Larutan Artifisial Fe dan Mn}

\section{Adsorpsi I - Desorpsi I}

\section{Adsorpsi I}

Adsorpsi I ditujukan untuk mendapatkan adsorben kulit jagung yang telah digunakan dalam penyishan logam $\mathrm{Fe}$ dan $\mathrm{Mn}$ dari larutan artifisial. Kondisi percobaan yang digunakan mengacu pada kondisi optimum proses adsorpsi $\mathrm{Fe}$ dan $\mathrm{Mn}$ dengan kulit jagung (Indah, dkk, 2007). Kapasitas adsorpsi I logam $\mathrm{Fe}$ dan $\mathrm{Mn}$ dapat dilihat pada Tabel 2. Berdasarkan data tersebut diperoleh kapasitas adsorpsi I logam Fe dan Mn hampir sama pada tiga kali percobaan. Masing-masing percobaan adsorpsi ini akan melalui proses desorpsi dengan tiga agen desorpsi yang berbeda.

Tabel 2. Kapasitas Adsorpsi I pada Larutan Artifisial Fe dan Mn

\begin{tabular}{cccc}
\hline \multirow{2}{*}{ Percobaan } & \multicolumn{2}{c}{ Kapasitas Adsorpsi I } & \multirow{2}{*}{ Untuk agen desorpsi } \\
\cline { 2 - 3 } & $\mathrm{Fe}$ & $\mathrm{Mn}$ & \\
\hline 1 & 0,309 & 0,098 & $\mathrm{HCl}$ \\
2 & 0,315 & 0,097 & $\mathrm{NaOH}$ \\
3 & 0,309 & 0,098 & Akuades \\
\hline
\end{tabular}

\section{Desorpsi I}

Proses desorpsi dilakukan terhadap kulit jagung yang telah digunakan pada percobaan adsorpsi I. Pada percobaan ini, volume agen desorpsi ditentukan berdasarkan perbandingan volume dari percobaan yang dilakukan oleh Wankasi et al. (2005) dimana sebanyak $0,25 \mathrm{~g}$ adsorben dimasukkan ke dalam tabung yang berisi $50 \mathrm{ml}$ agen desorpsi, sehingga jika berat optimum kulit jagung yang digunakan adalah seberat $2 \mathrm{~g}$ maka diperlukan volume agen desorpsi sebesar $400 \mathrm{ml}$. Adapun berat kulit jagung pada proses desorpsi I berkurang setelah digunakan pada proses adsorpsi I seperti terlihat pada Tabel 3 dan Tabel 4. Hal ini disebabkan karena kulit jagung yang telah digunakan tersebut dikeringkan terlebih dahulu sehingga kemungkinan ada jagung yang tertinggal di kertas saring, batang pengaduk dan kehilangan lain seperti pengaruh penggunaan $\mathrm{NaOH}$ dalam proses desorpsi. Persentase desorpsi (\% desorpsi) yang didapat pada desorpsi I logam $\mathrm{Fe}$ dan Mn dapat dilihat pada Tabel 5.

Berdasarkan data tersebut terlihat bahwa \% desorpsi lebih besar didapat pada agen $\mathrm{HCl}$ $0,1 \mathrm{M}$, baik untuk desorpsi logam $\mathrm{Fe}$ maupun logam Mn. Pada medium asam, gugus karboksil, karbonil, atau hidroksil pada adsorben menjadi terprotonasi dan tidak menarik ion logam yang bermuatan positif, sehingga terjadi pelepasan ion-ion logam ke dalam larutan atau agen desorpsi. Selain itu, pada media asam, proton-proton $\left(\mathrm{H}^{+}\right)$dalam larutan menggantikan ion-ion logam pada permukaan adsorben. Pada agen penukar proton seperti $\mathrm{HCl}$, ion-ion $\mathrm{H}^{+}$yang dilepaskan oleh $\mathrm{HCl}$ memiliki ikatan yang sangat kuat terhadap permukaan adsorben (Wankasi, et al., 2005). Jika dianalogikan dengan percobaan ini, pada saat $\mathrm{HCl}$ digunakan sebagai agen desorpsi, $\mathrm{H}^{+}$yang ada akan berusaha untuk berikatan dengan permukaan kulit jagung sehingga berkompetisi dengan ion-ion $\mathrm{Fe}$ dan $\mathrm{Mn}$ yang telah terikat di permukaan kulit jagung. Akibat kompetisi tersebut ion logam yang telah terikat dapat terlepas kembali ke larutan.

Persentase desorpsi yang rendah didapat pada agen basa yang kemungkinan disebabkan karena gugus-gugus tersebut menjadi kurang terprotonasi sehingga ionion logam yang berikatan sukar terlepas dari adsorben (Horsfall, et al., 2006). Wankasi, et al., (2005) juga menyatakan bahwa regenerasi dengan basa juga menyebabkan $\%$ desorpsi yang kecil karena basa tidak menyebabkan protonasi. Hal ini terbukti mengurangi pelepasan ion-ion $\mathrm{Fe}$ dan $\mathrm{Mn}$ dari kulit jagung.

Akuades menunjukkan kemampuan pemisahan logam yang paling rendah karena akuades tidak memiliki potensi reaksi pertukaran ion yang kompetitif seperti 
halnya asam dan basa. Akan tetapi, akuades mampu memisahkan ion-ion $\mathrm{H}^{+}$pada biosorben (Yan et al., 2001).

Tabel 3. Perbandingan Berat Kulit Jagung terhadap Volume Larutan pada Adsorpsi I Desorpsi I Logam Fe

\begin{tabular}{ccccc}
\hline \multicolumn{2}{c}{ Adsorpsi I } & \multicolumn{3}{c}{ Desorpsi I } \\
\hline $\begin{array}{c}\text { Berat } \\
\text { Adsorben }(\mathrm{g})\end{array}$ & $\begin{array}{c}\text { Volume } \\
\text { Larutan }(\mathrm{ml})\end{array}$ & $\begin{array}{c}\text { Berat } \\
\text { Adsorben }(\mathrm{g})\end{array}$ & $\begin{array}{c}\text { Volume } \\
\text { Agen }(\mathrm{ml})\end{array}$ & Agen \\
\hline 2 & 100 & 1,633 & 326,5 & $\mathrm{HCl}$ \\
2 & 100 & 1,590 & 318,0 & $\mathrm{NaOH}$ \\
2 & 100 & 1,542 & 308,3 & Akuades \\
\hline
\end{tabular}

Tabel 4. Perbandingan Berat Kulit Jagung terhadap Volume Larutan pada Adsorpsi I Desorpsi I Logam Mn

\begin{tabular}{ccccl}
\hline \multicolumn{2}{c}{ Adsorpsi I } & \multicolumn{3}{c}{ Desorpsi I } \\
\hline $\begin{array}{c}\text { Berat } \\
\text { Adsorben }(\mathrm{g})\end{array}$ & $\begin{array}{c}\text { Volume } \\
\text { Larutan }(\mathrm{ml})\end{array}$ & $\begin{array}{c}\text { Berat } \\
\text { Adsorben }(\mathrm{g})\end{array}$ & $\begin{array}{c}\text { Volume } \\
\text { Agen }(\mathrm{ml})\end{array}$ & Agen \\
\hline 2 & 100 & 1,818 & 363,5 & $\mathrm{HCl}$ \\
2 & 100 & 1,872 & 374,4 & $\mathrm{NaOH}$ \\
2 & 100 & 1,774 & 354,8 & Akuades \\
\hline
\end{tabular}

Tabel 5. Persentase Desorpsi I Logam Fe dan Mn

\begin{tabular}{lcc}
\hline \multicolumn{1}{c}{ Agen } & \% Desorpsi Logam Fe & \% Desorpsi Logam Mn \\
\hline $\mathrm{HCl}$ & 32,764 & 1,426 \\
$\mathrm{NaOH}$ & 10,894 & 1,075 \\
Akuades & 1,994 & 0,834 \\
\hline
\end{tabular}

Persentase desorpsi logam Fe lebih besar dibandingkan logam Mn karena kapasitas adsorpsi logam $\mathrm{Fe}$ juga lebih besar dibandingkan logam Mn. Artinya, semakin banyak logam yang terserap, maka kemungkinan terdesorpsi pun akan semakin besar. Berdasarkan penelitian tentang adsorpsi logam $\mathrm{Cd}$ dan $\mathrm{Hg}$ dengan Plerotus sapidus diperoleh kesimpulan bahwa kapasitas adsorpsi meningkat sesuai dengan peningkatan konsentrasi awal larutan (Yalcinkaya et al., 2001). Dari penelitian adsorpsi logam Fe dan Mn oleh kulit jagung yang telah dilakukan juga diperoleh kesimpulan bahwa kapasitas adsorpsi semakin besar sejalan dengan meningkatnya konsentrasi awal (Indah, dkk, 2007). Begitu pula pada penelitian ini, kapasitas adsorpsi I (awal) logam $\mathrm{Fe}$ lebih besar daripada kapasitas adsorpsi I logam Mn. Semakin besar konsentrasi awal logam maka kapasitas adsorpsi akan semakin besar sehingga persen desorpsi pun akan semakin tinggi.

\section{Adsorpsi II - Desorpsi II}

\section{Adsorpsi II}

Proses adsorpsi II merupakan reuse I dari kulit jagung yang sudah mengalami desorpsi I. Berat kulit jagung yang didapat akan menentukan volume larutan artifisial $\mathrm{Fe}$ atau Mn yang akan digunakan. Kapasitas adsorpsi logam Fe dan Mn untuk adsorpsi II (reuse I) yang dibandingkan dengan kapasitas adsorpsi pada adsorpsi I dapat dilihat Gambar 1 dan Gambar 2.

Berdasarkan Gambar 1, diperoleh penurunan kapasitas adsorpsi terhadap $\mathrm{Fe}$ terutama untuk kulit jagung yang telah didesorpsi dengan menggunakan agen $\mathrm{HCl}$ 0,1 $\mathrm{M}$ dan $\mathrm{NaOH}$ 0,1 M masing-masing menjadi $0,155 \mathrm{mg} \mathrm{Fe} / \mathrm{g}$ adsorben dan 0,096 $\mathrm{mg} \mathrm{Fe} / \mathrm{g}$ adsorben sedangkan akuades mengalami peningkatan kapasitas menjadi $0,329 \mathrm{mg} \mathrm{Fe} / \mathrm{g}$ adsorben. Sementara, pada Gambar 2 dapat dilihat kapasitas adsorpsi tertinggi terdapat pada kulit jagung yang telah mengalami proses desorpsi menggunakan akuades yaitu sebesar 0,094 mg Mn/g adsorben, disusul $\mathrm{NaOH} \mathrm{0,1} \mathrm{M}$ sebesar 0,090 mg Mn/g adsorben. Kapasitas adsorpsi paling rendah terjadi pada $\mathrm{HCl} 0,1$ $M$ yaitu sebesar 0,064 mg Mn/g adsorben.

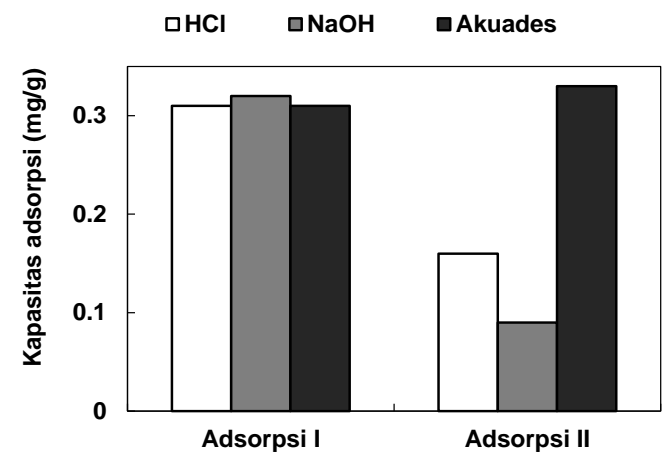

Gambar 1. Perbandingan Kapasitas Adsorpsi I dan Adsorpsi II Logam Fe.

Pada saat reuse kulit jagung yang telah didesorpsi dengan menggunakan akuades, kondisi $\mathrm{pH}$ akan tetap optimum karena akuades memiliki $\mathrm{pH}$ netral yang tidak akan mempengaruhi gugus fungsional yang terdapat pada kulit jagung sehingga kapasitas adsorpsi saat reuse tidak menurun secara drastis. Justru terjadi peningkatan penyerapan karena diperkirakan kulit jagung tersebut belum mengalami kejenuhan dan 
masih memiliki kemungkinan untuk menyerap logam Fe dan Mn. Kulit jagung tidak dipengaruhi adanya kenaikan ataupun penurunan $\mathrm{pH}$ sehingga kapasitas adsorpsi logam $\mathrm{Fe}$ dan $\mathrm{Mn}$ dari kulit jagung yang telah didesorpsi menggunakan akuades memiliki nilai yang terbesar. Penyebab lainnya adalah adanya kemampuan akuades untuk menyisihkan ion-ion $\mathrm{H}^{+}$dari permukaan adsorben (Yan et al.,, 2001), sehingga memberi kesempatan ion logam untuk terikat ke permukaan adsorben tersebut

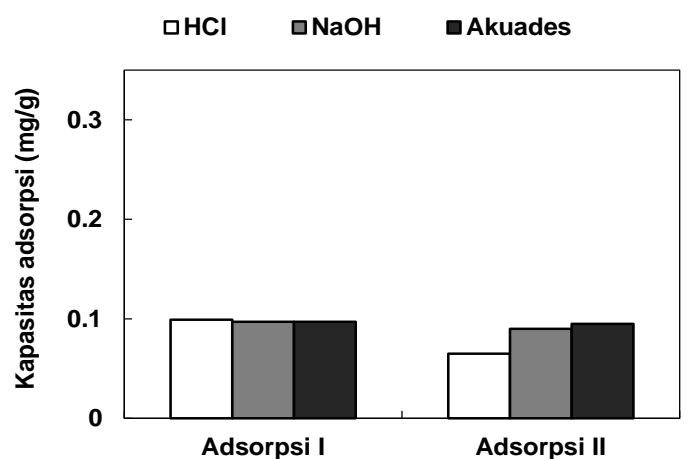

Gambar 2. Perbandingan Kapasitas Adsorpsi I dan Adsorpsi II Logam Mn.

Lebih rendahnya kapasitas adsorpsi $\mathrm{Fe}$ dan Mn pada kulit jagung yang telah didesorpsi dengan menggunakan $\mathrm{HCl}$ kemungkinan besar disebabkan pada saat reuse adsorben, sisa-sisa $\mathrm{HCl}$ masih tertinggal pada kulit jagung sehingga mengurangi adsorpsi ion logam $\mathrm{Fe}$ dan $\mathrm{Mn}$ pada kulit jagung. Walaupun $\mathrm{pH}$ optimum larutan artifisial $\mathrm{Fe}$ adalah 4 dan $\mathrm{Mn}$ adalah 5, tetapi dengan adanya sisa-sisa $\mathrm{HCl}$ pada kulit jagung tersebut menyebabkan kondisi larutan menjadi semakin asam dan ion-ion menjadi sukar terikat. Menurut Low et al. (1995), pada $\mathrm{pH}$ rendah permukaan adsorben akan bergabung secara dekat dengan ion-ion hidronium $\left(\mathrm{H}_{3} \mathrm{O}^{+}\right)$yang akan menghalangi ion logam ke permukaan gugus-gugus fungsional. Begitupun dengan kapasitas adsorpsi $\mathrm{Fe}$ dan $\mathrm{Mn}$ pada kulit jagung yang telah didesorpsi dengan $\mathrm{NaOH}$ yang menyebabkan kondisi $\mathrm{pH}$ melebihi optimum mengakibatkan adsorpsi ion logam $\mathrm{Fe}$ dan Mn pun akan menjadi semakin berkurang.

\section{Desorpsi II}

Percobaan dilakukan dengan menggunakan kulit jagung yang telah digunakan pada percobaan adsorpsi II (reuse I). Sama halnya dengan desorpsi I, pada desorpsi II ini juga terjadi pengurangan berat kulit jagung dan volume agen desorpsi. Perbandingan berat kulit jagung terhadap volume larutan pada adsorpsi II dan desorpsi II logam Fe dan Mn dapat dilihat pada Tabel 6 dan 7.

Tabel 6. Perbandingan Berat Kulit Jagung terhadap Volume Larutan pada Adsorpsi II Desorpsi II Logam Fe

\begin{tabular}{ccccl}
\hline \multicolumn{2}{c}{ Adsorpsi II } & \multicolumn{3}{c}{ Desorpsi II } \\
\hline $\begin{array}{c}\text { Berat } \\
\text { Adsorben }(\mathrm{g})\end{array}$ & $\begin{array}{c}\text { Volume } \\
\text { Larutan }(\mathrm{ml})\end{array}$ & $\begin{array}{c}\text { Berat } \\
\text { Adsorben }(\mathrm{g})\end{array}$ & $\begin{array}{c}\text { Volume } \\
\text { Agen }(\mathrm{ml})\end{array}$ & Agen \\
\hline 1,442 & 72,1 & 1,395 & 279,1 & $\mathrm{HCl}$ \\
0,996 & 49,8 & 0,846 & 169,2 & $\mathrm{NaOH}$ \\
1,386 & 69,3 & 1,286 & 257,1 & Akuades \\
\hline
\end{tabular}

Tabel 7. Perbandingan Berat Kulit Jagung terhadap Volume Larutan pada Adsorpsi II Desorpsi II Logam Mn

\begin{tabular}{ccccl}
\hline \multicolumn{2}{c}{ Adsorpsi II } & \multicolumn{3}{c}{ Desorpsi II } \\
\hline $\begin{array}{c}\text { Berat } \\
\text { Adsorben (g) }\end{array}$ & $\begin{array}{c}\text { Volume } \\
\text { Larutan }(\mathrm{ml})\end{array}$ & $\begin{array}{c}\text { Berat } \\
\text { Adsorben }(\mathrm{g})\end{array}$ & $\begin{array}{c}\text { Volume } \\
\text { Agen }(\mathrm{ml})\end{array}$ & Agen \\
\hline 1,644 & 82,20 & 1,593 & 318,6 & $\mathrm{HCl}$ \\
1,335 & 66,75 & 1,235 & 246,9 & $\mathrm{NaOH}$ \\
1,553 & 77,65 & 1,588 & 317,6 & Akuades \\
\hline
\end{tabular}

Berdasarkan perbandingan berat pada Tabel 6 dan 7 tersebut terlihat bahwa penggunaan $\mathrm{NaOH} \quad 0,1 \quad M \quad$ sebagai agen desorpsi menyebabkan berat adsorben lebih banyak berkurang dibandingkan dengan $\mathrm{HCl} 0,1 \mathrm{M}$ dan akuades. Kapoor et al. (1998) menyatakan dalam penelitiannya tentang adsorpsi logam $\mathrm{Cd}, \mathrm{Cu}, \mathrm{Ni}$ dan $\mathrm{Pb}$ pada biomaterial A. niger, aktivasi dengan $\mathrm{NaOH}$ mengurangi berat adsorbennya sekitar $26 \%$ selama proses adsorpsi sedangkan Fourest dan Volesky (1996) menyebutkan bahwa sekitar 39\% biomass Sargassum fluitans hilang setelah diaktivasi dengan $\mathrm{NaOH}$. Pada penelitian pemanfaatan biomaterial $M$. Rouxii untuk adsorpsi logam $\mathrm{Pb}, \mathrm{Cd}$, Ni dan $\mathrm{Zn}$, kehilangan berat adsorben terbesar pada proses aktivasi juga terjadi dengan menggunakan $\mathrm{NaOH}$ yaitu sebesar $13-29 \%$ (Yan et al., 2001). Pada dasarnya proses aktivasi maupun desorpsi sama-sama mereaksikan atau mengontakan adsorben biomaterial dengan $\mathrm{NaOH}$ sehingga selama 
proses desorpsi maupun adsorpsi berat adsorben menjadi berkurang.

Perbandingan \% desorpsi I dan \% desorpsi II logam $\mathrm{Fe}$ dan $\mathrm{Mn}$ dapat dilihat pada Gambar 3 dan Gambar 4. Pada Gambar 3 dan 4, terlihat bahwa pemisahan logam $\mathrm{Fe}$ maupun Mn dari adsorben kulit jagung semakin tinggi pada desorpsi kedua. Hal ini kemungkinan besar disebabkan terjadinya pengakumulasian ion-ion logam $\mathrm{Fe}$ maupun Mn setelah adsorpsi II. Sebelum adsorpsi II telah dilakukan desorpsi I yang mungkin tidak secara maksimal memisahkan ion-ion logam yang telah dijerap oleh kulit jagung pada adsorpsi I. Kemudian pada saat adsorpsi II, kulit jagung belum mengalami kejenuhan sehingga masih dapat menyerap ion-ion logam.

Selain itu, menurut Wankasi et al. (2005), \% desorpsi juga tergantung pada waktu, dimana dari hasil percobaanya didapatkan bahwa dengan memperpanjang waktu kontak diperoleh peningkatan \% desorpsi. Dalam hal penelitian ini, proses desorpsi yang kedua membuat waktu kontak menjadi lebih panjang sehingga dapat meningkatkan $\%$ desorpsi.

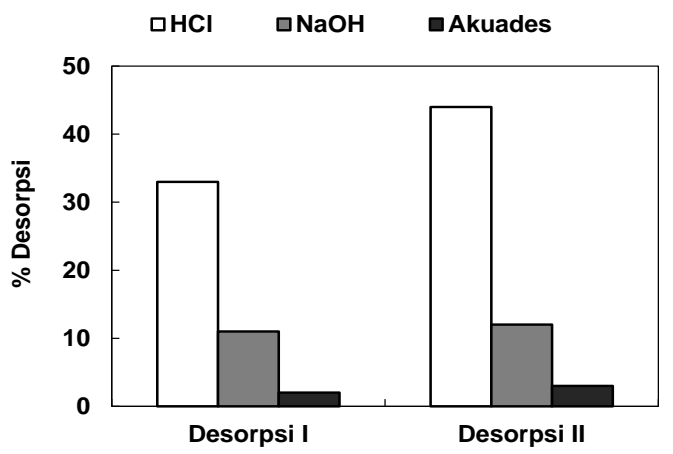

Gambar 3. Perbandingan Persen Desorpsi I dan Desorpsi II Logam Fe.

Untuk agen desopsi, sama halnya dengan desorpsi I, pada desopsi II, agen $\mathrm{HCl}$ menghasilkan \% desorpsi yang lebih tinggi dibanding $\mathrm{NaOH}$ dan akuades. Hal ini menegaskan bahwa media asam mengandung konsentrasi proton yang tinggi dan bisa menggantikan ion-ion yang berikatan pada sisi aktif permukaan adsorben dibandingkan ion-ion hidroksil $\left(\mathrm{OH}^{-}\right)$. Sementara, sama halnya pada desorpsi I, akuades menunjukkan kemampuan pemisahan logam yang paling rendah karena akuades tidak memiliki potensi reaksi pertukaran ion yang kompetitif seperti halnya asam dan basa.

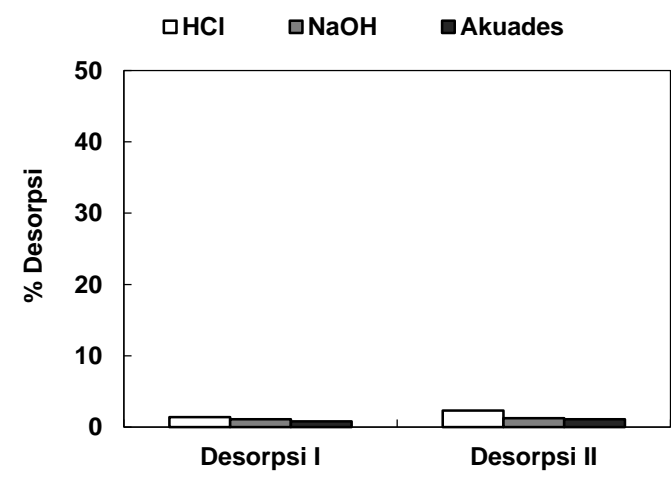

Gambar 4. Perbandingan Persen Desorpsi I dan Desorpsi II Logam Mn.

\section{Adsorpsi III}

Percobaan adsorpsi III merupakan reuse 2 bagi kulit jagung setelah dilakukan desorpsi II. Perbandingan kapasitas adsorpsi logam Fe dan Mn dapat dilihat pada Gambar 5 dan 6.

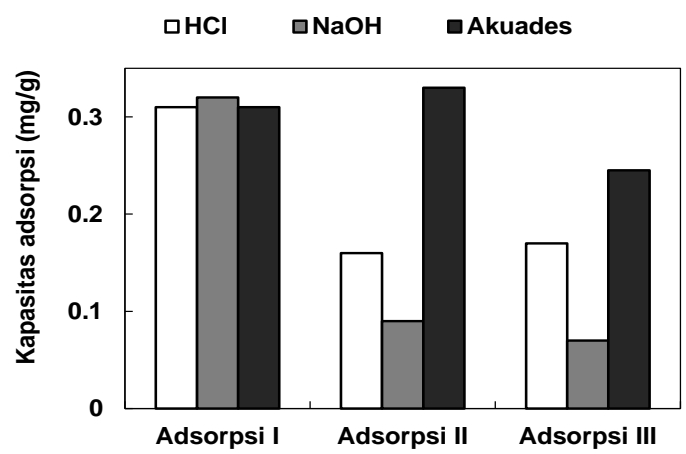

Gambar 5. Perbandingan Kapasitas Adsorpsi Logam Fe.

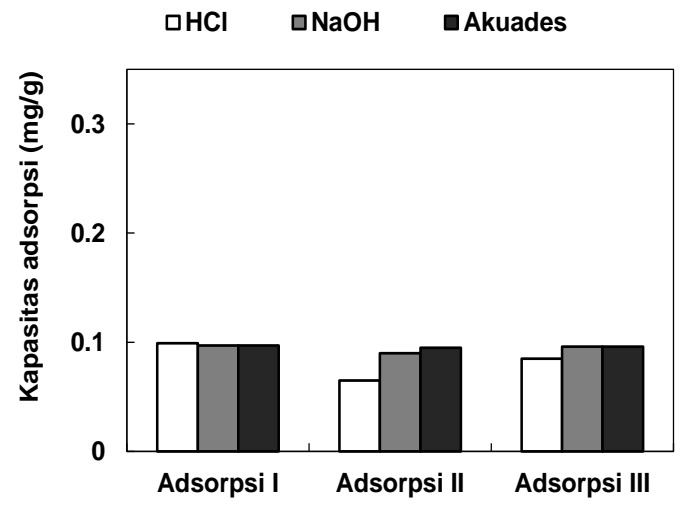

Gambar 6. Perbandingan Kapasitas Adsorpsi Logam Mn. 
Pada adsorpsi III, kapasitas penyerapan paling tinggi tetap pada akuades yaitu sebesar 0,246 $\mathrm{mg} \mathrm{Fe} / \mathrm{g}$ adsorben, walaupun terjadi penurunan dibanding adsorpsi II. Kemudian disusul $\mathrm{HCl}$ dan $\mathrm{NaOH}$ masingmasing $0,179 \mathrm{mg} \mathrm{Fe} / \mathrm{g}$ adsorben dan 0,080 $\mathrm{mg} \mathrm{Fe} / \mathrm{g}$ adsorben (Gambar 5). Adanya kenaikan pada kapasitas adsorpsi kulit jagung yang telah didesorpsi dengan $\mathrm{HCl}$ kemungkinan disebabkan karena $\%$ desorpsi II juga lebih besar daripada desorpsi I. Penurunan kapasitas adsorpsi kulit jagung yang telah didesorpsi dengan $\mathrm{NaOH}$ disebabkan adanya pengaruh ion-ion $\mathrm{OH}^{-}$ yang semakin bertambah pada permukaan kulit jagung sehingga memperkecil peluang terikatnya ion-ion logam Fe. Penurunan kapasitas yang terjadi pada adsorpsi III kemungkinan disebabkan menurunnya kemampuan kulit jagung dalam menyerap logam Fe.

Berdasarkan Gambar 6, kapasitas adsorpsi Mn tertinggi pada adsorpsi III didapat dari kulit jagung yang telah mengalami proses desorpsi menggunakan $\mathrm{NaOH}$ yaitu sebesar 0,097 mg Mn/g adsorben disusul akuades sebesar 0,096 mg Mn/g adsorben dan $\mathrm{HCl}$ sebesar $0,081 \mathrm{mg} \mathrm{Mn} / \mathrm{g}$ adsorben. Di sini terlihat bahwa kapasitas adsorpsi setelah kulit jagung didesorpsi dengan menggunakan akuades dan $\mathrm{NaOH}$ tidak mempunyai perbedaan yang signifikan.

\section{Analisis Agen Desorpsi}

Berdasarkan data percobaan, kapasitas adsorpsi kulit jagung untuk akuades hampir sama untuk ketiga percobaan adsorpsi (adsorpsi I sampai III). Walaupun akuades tidak efektif dalam hal recovery ion-ion logam dari adsorben, tapi akuades memberikan pengaruh pada saat reuse adsorben sehingga bisa diregenerasi. Pada saat reuse, kulit jagung yang telah didesorpsi logamnya menggunakan akuades, kondisi pH akan tetap optimum karena akuades bersifat netral sehingga kapasitas adsorpsi saat reuse tidak menurun secara drastis.

Berdasarkan kapasitas adsorpsi yang lebih tinggi tersebut, dapat disimpulkan bahwa akuades merupakan agen terbaik dalam regenerasi kulit jagung yang telah digunakan dalam adsorpsi logam-logam $\mathrm{Fe}$ dan $\mathrm{Mn}$. Selain dilihat dari segi kapasitas adsorpsi yang baik, penggunaan akuades dalam regenerasi kulit jagung lebih memberikan nilai ekonomis dibandingkan $\mathrm{HCl}$ dan $\mathrm{NaOH}$ karena lebih murah, praktis, dan mudah didapat.

Percobaan dengan Menggunakan Sampel Air Tanah Asli

Berdasarkan hasil analisis sampel air tanah, diperoleh konsentrasi awal dari titik sampel yang dapat dilihat pada Tabel 9. Nilai konsentrasi awal sampel air tanah terlihat melebihi baku mutu yang telah ditetapkan. Berdasarkan kondisi tersebut maka diperlukan adanya pengolahan yang dapat menurunkan konsentrasi logam $\mathrm{Fe}$ dan $\mathrm{Mn}$ dari air tanah hingga memenuhi standar yang telah ditetapkan. Pada percobaan ini digunakan kondisi optimum yang diperoleh dari percobaan optimasi. Adapun agen yang digunakan pada percobaan aplikasi ini adalah akuades berdasarkan analisis agen desorpsi. Hasil percobaan adsorpsi dan desorpsi terhadap sampel air tanah dapat dilihat pada Gambar 7 dan 8.

Tabel 9. Konsentrasi Awal Logam dalam Sampel Air Tanah

\begin{tabular}{clcc}
\hline No & Logam & $\begin{array}{c}\text { Konsentrasi } \\
(\mathrm{mg} / \mathrm{l})\end{array}$ & $\begin{array}{c}\text { Baku Mutu* } \\
(\mathrm{mg} / \mathrm{l})\end{array}$ \\
\hline 1 & $\mathrm{Fe}$ & 11,898 & 0.3 \\
2 & $\mathrm{Mn}$ & 1,032 & 0.1 \\
\hline
\end{tabular}

Pada Gambar 7, dapat dilihat perbandingan kapasitas adsorpsi kulit jagung terhadap logam Fe dan Mn. Pada adsorpsi II dan III, terlihat kestabilan kapasitas adsopsi dengan tidak terjadinya penurunan yang signifikan. Kapasitas adsorpsi logam Fe adalah 0,433 g $\mathrm{Fe} / \mathrm{g}$ kulit jagung dan $0,430 \mathrm{~g} \mathrm{Fe} / \mathrm{g}$ kulit jagung pada adsorpsi I dan II sementara kapasitas adsorpsi logam Mn adalah 0,044 g $\mathrm{Mn} / \mathrm{g}$ kulit jagung dan 0,043 g Mn/g kulit jagung. Penurunan kapasitas pada adsorpsi III terhadap logam $\mathrm{Fe}$ disebabkan \% desorpsi II logam $\mathrm{Fe}$ juga menurun dan kemampuan kulit jagung semakin berkurang (Gambar 8). Sementara pada adsorpsi III logam Mn juga terjadi penurunan \% desorpsi walaupun tidak signifikan padahal terjadi kenaikan pada \% desorpsi II. Hal ini kemungkinan juga disebabkan berkurangnya kemampuan kulit jagung dalam menyerap logam Mn. 
Gambar 8 menunjukan \% desorpsi yang didapatkan pada desorpsi I dan II untuk logam Fe dan Mn. Persentase desorpsi I dan II logam Fe dari kulit jagung yaitu 3,335\% dan 2,033\% sementara \% desorpsi I logam Mn dari kulit jagung sebesar 1,311\% dan \% desorpsi II sebesar 2,110\%. Dapat dilihat bahwa \% desorpsi yang diperoleh pada percobaan menggunakan sampel air tanah asli lebih rendah, terutama untuk logam $\mathrm{Fe}$, dibanding dengan $\%$ desorpsi yang diperoleh pada percobaan menggunakan larutan artifisial. Hal ini disebabkan kompleksnya matriks yang terkandung dalam sampel air tanah asli, sehingga kemungkinan menghambat proses desorpsi logam $\mathrm{Fe}$ dan Mn dari adsorben kulit jagung.

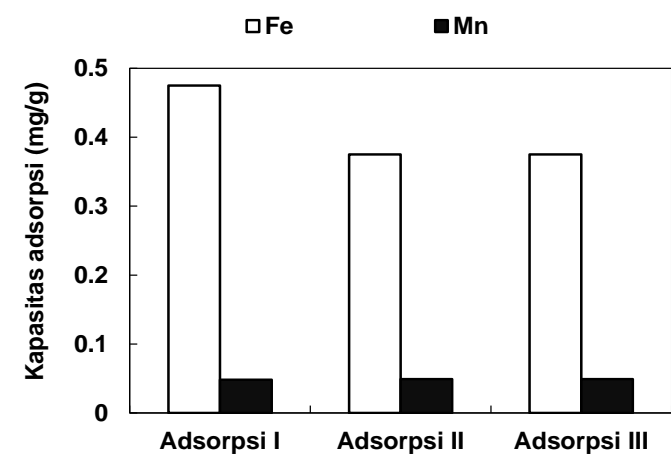

Gambar 7. Kapasitas Adsorpsi Logam Fe dan Mn pada percobaan menggunakan sampel air tanah asli

Kembali tentang kapasitas adsorpsi, perbedaan kapasitas adsorpsi pada percobaan dengan larutan artifisial dan sampel air tanah asli dapat disebabkan keberadaan ion logam lain dalam sampel air tanah asli. Sampel sebelum diadsorpsi tidak mengalami perlakuan pendahuluan. Oleh karena itu, ion logam $\mathrm{Fe}$ dan $\mathrm{Mn}$ berkompetisi dengan ion logam terlarut lainnya untuk menempati permukaan aktif adsorben. Diketahui bahwa dalam air tanah selain logam besi $(\mathrm{Fe})$ atau mangan $(\mathrm{Mn})$ yang merupakan ion mayor, juga mengandung ion-ion logam terlarut lainnya seperti arsen (As), barium (Ba), kadmium $(\mathrm{Cd})$, kromium $(\mathrm{Cr})$, kobalt $(\mathrm{Co})$, tembaga $(\mathrm{Cu})$, timbal $(\mathrm{Pb})$, nikel $(\mathrm{Ni})$, seng $(\mathrm{Zn})$, strontium ( $\mathrm{Sr}$ ), dan selenium (Se) yang dikategorikan sebagai ion minor (Effendi, 2003). Hal ini menunjukkan bahwa proses adsorpsi dipengaruhi oleh konsentrasi adsorbat, yaitu semakin besar konsentrasi adsorbat dalam larutan, maka semakin banyak juga jumlah yang terserap pada permukaan adsorben (Eckenfelder, 2000)

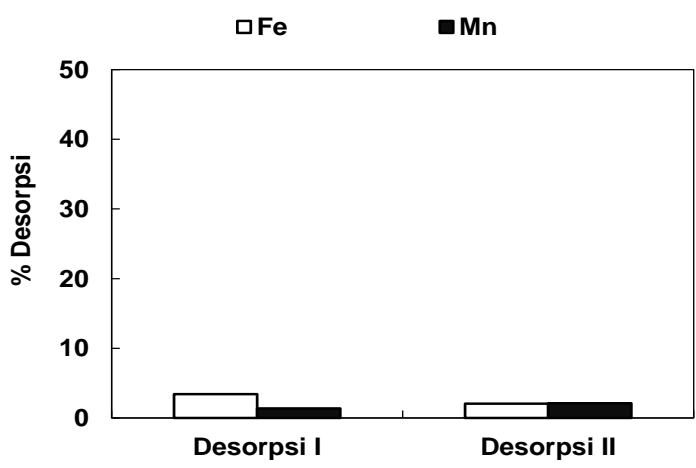

Gambar 8. Persentase Desorpsi Logam Fe dan Mn pada percobaan menggunakan sampel air tanah asli

Berdasarkan data percobaan menggunakan sampel air tanah asli, kapasitas adsorpsi Fe dan Mn oleh kulit jagung dengan akuades sebagai agen desorpsinya, menujukan nilai yang hampir sama untuk ketiga percobaan adsorpsi. Dari data tersebut dapat disimpulkan bahwa kulit jagung dapat diregenerasi tanpa penurunan kapasitas adsorpsi yang drastis dengan menggunakan agen desorpsi akuades.

\section{SIMPULAN}

Berdasarkan penelitian yang telah dilakukan dapat diambil kesimpulan sebagai berikut:

Agen desorpsi yang menghasilkan \% desorpsi tertinggi untuk logam $\mathrm{Fe}$ dan $\mathrm{Mn}$ dari kulit jagung adalah $\mathrm{HCl} \mathrm{0,1} \mathrm{M,} \mathrm{dimana}$ diperoleh \% desorpsi sebesar $32,764 \%$ dan $43,750 \%$ untuk $\mathrm{Fe}$ dan $1,426 \%$ dan 2,358\% untuk Mn, masing-masing pada desorpsi I dan II. Hal ini menunjukan bahwa $\mathrm{HCl} 0,1$ $\mathrm{M}$ merupakan agen desorpsi terbaik untuk recovery logam Fe dan Mn dari kulit jagung.

Dari segi kapasitas adsorpsi, akuades merupakan agen terbaik dalam regenerasi kulit jagung yang telah digunakan untuk menyisihkan logam-logam $\mathrm{Fe}$ dan $\mathrm{Mn}$ dibanding agen desorpsi $\mathrm{HCl} 0,1 \mathrm{M}$ dan $\mathrm{NaOH} 0,1 \mathrm{M}$, dimana didapat kapasitas 
adsorpsi yang lebih besar dan relatif stabil pada dua kali reuse yaitu $0,329 \mathrm{mg} \mathrm{Fe} / \mathrm{g}$ dan 0,246 mg Fe/g untuk Fe dan 0,094 mg Mn/g dan 0,096 $\mathrm{mg} \mathrm{Mn/g}$ untuk Mn, masingmasing pada reuse I dan II.

Dari percobaan uji regenerasi kulit jagung dalam menyisihkan logam $\mathrm{Fe}$ dan Mn dari sampel air tanah asli dengan menggunakan akuades sebagai agen desorpsi diperoleh kapasitas adsorpsi logam $\mathrm{Fe}$ sebesar 0,433 g $\mathrm{Fe} / \mathrm{g}$ dan $0,430 \mathrm{~g} \mathrm{Fe} / \mathrm{g}$ kulit jagung, sementara kapasitas adsorpsi logam Mn adalah $0,044 \mathrm{~g} \mathrm{Mn} / \mathrm{g}$ dan 0,043 g Mn/g kulit jagung, masing-masing pada adsorpsi I dan II.

Dilihat dari kemampuan adsorpsinya untuk menyisihkan logam Fe dan Mn setelah dua kali reuse, regenerasi kulit jagung menggunakan akuades sangat mungkin untuk dilakukan.

\section{UCAPAN TERIMA KASIH}

Penulis mengucapkan terima kasih atas bantuan dana untuk penelitian ini kepada DIPA Universitas Andalas, sesuai dengan Surat Perjanjian Pelaksanaan Pekerjaan Penelitian Nomor : 088/H.16/PL/DIPA/I/ 2009, tanggal 2 April 2009

\section{DAFTAR PUSTAKA}

Alaerts \& Santika. 1984. Metode Penelitian Air. Surabaya: Usaha Nasional

Al-Layla, M.A., Shamim, A., 1977. Water Supply Engineering Design, Ann Arbor Science, Michigan.

Eckenfelder, W.W., 2000, Industrial Water Pollution Control. Mc Gaw-Hill, $3^{\text {rd }}$ edition, Singapore.

Effendi, H., 2003, Telaah Kualitas Air Bagi Pengelolaan Sumber Daya dan Lingkungan Perairan, Kanisius, Yogyakarta.

Fourest, E., and Volesky, B., 1996, Contribution of sulphonate groups and alginate to heavy metal biosorption by the dry biomass os Sargassum fluitans, Environmental Science Technology, 30, pp. 277-282.

Horsfall, M., Ogban, F.E., Akporhonor, E.E, 2006, Recovery of Lead and Cadmium
Ions from Metal-Loaded Biomass of Wild Cocoyam (Caladium bicolor) Using Acidic, Basic and Neutral Eluent Solutions, Electronic Journal of Biotechnology, Vol. 9 No. 2, Issue of April 15, 2006

Igwe, J.C, Ogunewe, D.N., Abia, A. A., 2005, Competitive Adsorption of $\mathrm{Zn}$ (II), Cd (II), and $\mathrm{Pb}$ (II) Ions from Aqueous and Non-Aqueous Solution by maize $\mathrm{Cob}$ and Husk. African Journal of Biotechnology Vol. 4 (10), pp. 1113-1116.

Indah dkk, 2007, Penyisihan Logam Besi (Fe) dan Mangan (Mn) dalam Air Tanah dengan Menggunakan Kulit Jagung (Zea mays L.) sebagai Adsorben, Laporan Penelitian, Dana DIPA Universitas Andalas Tahun Anggaran 2007.

Kapoor, A., Viraraghavan, T., Cullimore, D.R., 1999, Removal of heavy metals using the fugal Aspergillus niger, Bioresources Technology, 70, pp. 95104.

Kawamura, S., 1991, Integrated Design of Water Treatment Facilities. New York: John Willey an Sons, Inc.

Kurakake, M., Kisawa, W., Ouchi, K., Komaki, T., 2001, Pretreatment with ammonia water for enzymatic hydrolysis of corn husk, bagasse, and switchgrass. Applied Biochemistry and Biotechnology, 90 (3), pp. 251259.

Mardona. 2007. Pengaruh Variasi Laju Alir Influen dan Diameter Adsorben Kulit Jagung (Zea mays l.) terhadap Penyerapan Kromium (VI) dalam Air. Tugas Akhir, Jurusan Teknik Lingkungan, Fakultas Teknik Universitas Andalas. Padang

Montgomery, J.M., 1985, Water Treatment Principles and Design, Consulting Engineering, Inc., USA

Low, K. S., Lee, C. K., Leo, A.C., 1995, Removal of metals from electroplating wastes using banana pith, Bioresource Technology, 51 pp. 227-231

Munaf, E \& Zein, R. 1997. The Use of Rice Husk for Removal of Toxic Metals from Waste Water. Environmental Technology, 18 (3), pp. 359-362.

Munaf, E., Haryati, S., Suyani, H., Dharma, A., 2000, Penyerapan Ion Kromium 
(III) dan Kromium (VI) dalam Air dengan menggunakan Tepung Enceng Gondok dan Studi Regenerasinya. Jurnal Kimia Andalas, 6 (2), hal. 6877.

Somerville, R. (2007). Low-cost adsorption materials for removal of metals from contaminated water. Master Thesis, KTH Architecture and the Built Environment

Wankasi, D., Horsfall, M. Jnr, Spiff, A. I., 2005. Desorption of $\mathrm{Pb}^{2+}$ and $\mathrm{Cu}^{2+}$ from Nipa Palm (Nypa fruticans Wurmb) Biomass. African Journal of Biotechnology, Vol. 4 (9), pp. 923927.

Yalcinkaya, Y., Arica, M.Y., Soysal, L., Denizli, A., Genc, O., Bektas, S., 2002, Cadmium and Mercury Uptake by Immobilized Pleurotus sapidus, Turk J Chem, 26, pp. 441- 452.

Yan, G., Viraraghavan, T., 2003, Heavy-metal removal from aqueous solution by fungus Mucor rouxii, Water Research, Vol. 37(18), pp. 4486-4496 sisa klor sesuai dengan persamaan 1 (Lee, 2007). 